\title{
Sosyal Medya Pazarlamasının Kurumsal İtibar Algısına Etkisi: Kişiselleştirme Metaforu ${ }^{1}$
}

\author{
PInar BAȘGÖZE \\ Sorumlu Yazar, Hacettepe Üniversitesi, IIIBF, Isşletme Bölümü \\ pinaran@hacettepe.edu.tr, ORCID: 0000-0003-4597-5752
}

Hülya ÖZDESTICİ YÖRÜK

Hacettepe Üniversitesi, SBE, İsletme Ana Bilim Dalı

hulya@netvent.com,ORCID:0000-0002-2434-9798

\begin{abstract}
Öz
Bu çalışmanın amacı, algılanan sosyal medya pazarlamasının kurumsal itibar algısı üzerindeki etkisinin incelenmesidir. Günümüze dek sosyal medya ve kurumsal itibar arasındaki ilişkiyi farklı yaklaşımlarla ele alan çalışmalar bulunmaktadır. Bu çalışmada benzer çalışmalardan farklı olarak, sosyal medya algısının ve boyutlarının (eğlence, etkileşim, eğilim, özelleştirme, kulaktan kulağa iletişim) "kişiselleştirme metaforu" yaklaşımıyla ölçülen kurumsal itibar algısı boyutları üzerindeki etkilerini ölçmeye yönelik yeni bir araştırma modeli önerilmiştir. Çalışmanın araştırma sorularının test edilmesi amacıyla basit doğrusal ve çoklu regresyon analizleri kullanılmıştır. Kolayda örneklem yöntemi benimsenerek, birincil veri elde edilmiş ve 250 katılımcıdan veri toplanmıştır. Yapılan analizler sonucunda, tüketicinin markaya yönelik sosyal medya algısının kurumsal itibar algısını olumlu etkilediği bulunmuştur. Buna ek olarak kurumsal itibar algısını, algılanan sosyal medya boyutları arasından en fazla alan eğlence, eğilim ve etkileşim boyutlarının etkisi olduğu saptanmıştır.

Anahtar Sözcükler: Algılanan Sosyal Medya, Kurumsal İtibar Algısı, Kişiselleştirme Metaforu

Jel Sinıflandırma Kodu: M31

Effects of Perceived Social Media Marketing on Corporate Reputation Perception: Personification Metaphor ${ }^{2}$

Abstract

The aim of the study is to investigate the effects of perceived social media on corporate reputation. Although, the vast majority of the researches examine the same relation, this study contributes to the literature by analyzing the distinct effects of perceived social media dimensions (entertainment, interaction, trendiness, customization, word of mouth) on corporate reputation perception dimensions. While investigating this relationship corporate reputation was measured by "Personification Metaphor" approach. Thus, linear regression and multiple regression analyses were conducted in order to analyze the research questions. Primary data and the convenience sampling method preferred for the model testing. Data was collected from 250 participants. According to the empirical results, consumer's perception of social media marketing significantly and positively affects corporate reputation perception. Moreover, entertainment, interaction and trendiness dimensions of perceived social media marketing have utmost effects on corporate reputation perception.
\end{abstract}

Keywords: Perceived Social Media, Corporate Reputation Perception, Personification Metaphor Jel Classification Codes: M31

\footnotetext{
${ }^{1}$ Yazarlardan Hülya Özdestici Yörük'ün Doç. Dr. Pınar Başgöze danışmanlığında 2018 yılında Tamamladığı "Algılanan Sosyal Medya Pazarlamasının Kurumsal İtibar Algısına Etkisi Üzerine Bir Araştırma" başlıklı yüksek lisans tezinden türetilmiştir.

${ }^{2}$ Extended abstract is presented at the end of the article
}

Geliş Tarihi (Received): 07.07.2020 - Kabul Edilme Tarihi (Accepted): 16.02.2021

Attfta bulunmak için / Cite this paper:

Başgöze, P. ve Özdestici Yörük, H. (2021). Sosyal medya pazarlamasının kurumsal itibar algısına etkisi: Kişiselleştirme metaforu. Çankırı Karatekin Üniversitesi İ̈BF Dergisi, 11 (1), 95-127. Doi: 10.18074/ckuiibfd.766170. 


\section{Giriş}

Günümüzde sosyal medya kullanımı, markaların kendilerini tüketicilerine daha hızlı, daha az maliyetli ve daha esnek biçimde ifade etme şansı tanırken, aynı zamanda sosyal medya aracılığı ile kurdukları iletişim ve ürettikleri içerikler sayesinde kurumsal imaj ve itibarlarını yönetebilme firsatı da tanımaktadır. Öte yandan sosyal medya geleneksel medyadan farklı olarak, kullanıcıya; markalarla ilgili yorum yapma, içerik üretme ve anlık olarak fikir beyan etme hakkı vermektedir. Bu farklılık ise avantaj sağlamanın yanında yönetimesinin zorluğu bakımından da dezavantaja dönüşebilmektedir. Ancak sosyal medya, her ne kadar yönetimi zor olsa da kurumlar tarafından etkin biçimde kullanılması, kurumsal itibar açısından önem taşıması sebebi ile ölçülmesi ve sonuçlarının değerlendirilmesi gereken önemli kavramlar arasındadır (Aydın, 2015).

Kurumsal itibar, işletmeler için önemi giderek artan ve işletmelerin daha gerçekçi biçimde ölçmek istedikleri bir kavram olarak karşımıza çıkmaktadır. Ancak bir yandan da kurumsal itibarın soyut yapısı dolayısıyla mevcut ölçeklerle ölçülmesi zor olabilmektedir. Bu nedenle literatürde kurumsal itibarı doğru ölçmek adına çeşitli çalışmalar yer almaktadır (ör. MacMillan, Money, Downing ve Hillenbrand, 2005). Kişiselleştirme metaforu da tüketicinin kurumsal itibar algısını ölçmek için kullanılan önemli yaklaşımlardan bir tanesidir (Davies, Chun, Silva ve Roper, 2001). Marka kişiliği (Aaker, 1997) yaklaşımından yola çıkılarak geliştirilen bu yöntemle birlikte, kurumsal itibar algısının ölçümünde insana özgü özelliklerin kurumlara atfedilmesi hedeflenmektedir (Davies ve Chun, 2003). Literatürde kurumsal itibarın önem kazanması ile birlikte birçok faktörle arasındaki ilişki çalışmalara konu olmuştur. Bunlardan bazıları; güven, kurumsal iletişim, kurumsal performans, tatmin, örgütsel bağl1lık ve müşteri sadakatidir (ör. Andreassen ve Lindestad, 1998; Robertson, 1993; Yoon, Guffey ve Kijewski, 1993). Günümüzde ise sosyal medya kullanımının artması ile birlikte tüketicilerin kurumsal itibar değerlendirmelerinde markaların sosyal medya hesapları kurumsal itibar algısını etkileyen önemli kaynaklardan bir tanesi haline gelmiştir. Her ne tüketicilerin markaları sosyal medya hesaplarına göre değerlendirmeleri artma eğiliminde olsa da, kurumsal itibar ile sosyal medya arasındaki ilişkiyi açıklayan çalışmaların (Floreddu, Cabiddu ve Evaristo, 2014) görece kısıtlı oluşu dikkat çekmektedir.

Tüketicilerin markaları sosyal medya üzerinden takip ettikleri ve söz konusu markaları bir "kişı" olarak algıladıkları günümüz ekosisteminde; markaların kurumsal itibarının sosyal medya kullanımlarından nasıl etkilendiğini belirlemek gerekmektedir. Dolayısıyla, çalışmanın temel amacı tüketicinin markaların sosyal medya pazarlama faaliyetlerine yönelik algıları ile markaya yönelik algıladığı kurumsal itibar arasındaki ilişkinin incelenmesidir. Bu anlamda çalışma, kurumsal itibarın "kişiselleştirme metaforu" kullanılarak ölçülmesi ve kurumsal itibar ile sosyal medya algısı boyutlarının ayrı ayrı etkilerinin incelenmesi bakmından 
literatüre katkı sağlayabilecektir. Çalışmanın öngörülen bir diğer katkısı ise, sosyal medya pazarlamasına yönelik algıların ve kurumsal itibar algısının ölçümünde, "birey" kavramına odaklanarak; bireyin algıları, istekleri ve özelliklerinin ön planda olduğu bir yaklaşımın benimsenmesidir. Çalışmada tüketicinin Panora AVM'ye yönelik olarak sosyal medya algısı ölçülmüş ve bu algının, tüketicinin Panora AVM'nin kurumsal itibarına yönelik algısı üzerine etkileri incelenmiş, böylelikle elde edilen bulgular doğrultusunda AVM sektörüne özel stratejiler önerilmiştir.

Çalışmada üç kısım yer almaktadır. Bunlar; literatür araştırması, araştırmanın metodolojisi ve bulgular ile tartışma kısmlarıdır.

\section{Literatür Araștırması}

\subsection{Sosyal Medyanın Pazarlamada Kullanımı ve Algılanan Sosyal Medya}

Günümüzde pazarlamacılar yalnızca firmaların mesajlarını tüketicilere ilettiği tek yönlü iletişim yerine, tüketicilerin de üretilen mesajlara kolaylıkla karşılık verebilecekleri etkileşimli iletişim kanallarını benimsemektedirler (Groom, 2008). Söz konusu etkileşimli iletişim kanallarından bir tanesi de sosyal medya kanallarıdır. Kaplan ve Haenlein (2010) tarafindan sosyal medya, Web 2.0 kavramının ideolojik ve teknolojik temelleri üzerine kurulan ve kullanıcıya içerik üretme ve bu içeriği yayma hakkı tanıyan, internet tabanlı uygulamalar bütünü olarak ifade edilmiştir. Bu bağlamda tüketicilerin giderek artan bir biçimde sosyal medyayı günlük yaşamlarının önemli parçalarından biri haline getirdikleri ve sosyal etkileşimlerini de daha çok sanal platformlara (Facebook, Twitter, Instagram vb.) taşıdıkları ifade edilmiştir (Alalwan, Rana, Dwivedi ve Algharabat, 2017). Bu nedenle, sosyal medya pazarlaması da birçok farklı çalışma 1şığında pazarlama iletişimi karmasının kritik bir bileşeni olarak görülmeye başlanmıştır.

Literatürde yer alan çalışmalara (Gordhamer, 2009; Chi, 2011) göre, sosyal medya pazarlaması markalar ve tüketiciler arasında bağ kurmayı sağlayan, kullanıcı merkezli, etkileşim içeren kişiselleştirilmiş bir kanalın iletişim amacı ile kullanılmasıdır. Ancak literatürde hâlâ markaların, sosyal medya pazarlamasını yerinde ve amacına uygun olarak kullanımlarının kısıtlı olduğu görüşü hâkimdir (Gensler, Völckner, Liu-Thompkins ve Wiertz, 2013; Weinberg ve Pehlivan, 2011; Kim ve Ko, 2012). Bu doğrultuda literatürde yer alan birçok çalışma (Weinberg, 2009; Zarrella, 2009; Evans, 2010; Packer, 2011; Kaur, 2016; Tuten ve Solomon, 2017), sosyal medya pazarlamasının işlevini ve sınırlarını değerlendirmeye çalışmıştır.

Sosyal medyanın kullanımı ile birlikte işletmelerin kontrolünde olan tüketici faaliyetleri değişmiştir. Böylece, işletmeler sosyal medyanın kullanımından fayda sağlayabilmek için bu yeni dinamikleri ve değişen tüketici davranışlarını doğru anlamak durumundadırlar (Heinonen, 2011). Tüketicilerin büyük kısmının sosyal 
medyada etkin biçimde yer aldığı bir ekosistemde, işletmeler de sosyal medya etkinliklerini arttırmalılardır (Tiago ve Verissimo, 2014). Dolayısıyla işletmeler, dijitalleşme, sosyal medya kullanımı ve değişen tüketici davranışları doğrultusunda, pazarlama stratejilerini tekrar değerlendirmelilerdir.

Keskin ve Baş'ın (2016) çalışmalarına göre, sosyal medya; tüketicilerin güncel haberleri, arkadaşlarını ve diğer bireylerin fikirlerini takip ettikleri; bununla birlikte markalara ilişkin fikir edindikleri bir kanal işlevi görmektedir. Bu kanalın kullanımı ile oluşturulan sosyal medya pazarlaması stratejilerinin de tüketici davranışları üzerine etkileri mevcuttur. DEI Worldwide ${ }^{3}$ (2008)'ın sosyal medyanın satın alma davranışı üzerindeki etkisini incelediği araştırmasının sonucuna göre, tüketicilerin \%70'inin markalar hakkında bilgi almak için sosyal medyayı kullandığı, \%49'unun sosyal medya üzerinden edindiği bilgiler doğrultusunda satın alma kararı verdiği ortaya çıkmıştır. Lempert (2006), çalışmasında tüketicilerin bilgi araştırması yaparken ve satın alma kararlarını yönetirken sıklıkla markaların çeşitli sosyal medya kanallarına başvurduğunu belirtmiştir. Alabay'a (2011) göre, söz konusu ağların, işletmelerin ürün bilgilerinin ve marka bilgilerinin şeffaf hale gelmesini sağlamakta, tüketicilere markalar ile ilgili önemli bilgiler sunmakta ve bu nedenle satın alma davranışı üzerine etkileri olabilmektedir.

Sosyal medya pazarlaması satın alma davranışının yanı sıra müşteri ilişkilerini de etkilemektedir (Kim ve Ko, 2010). Tüketiciler sosyal medya pazarlamasını kullanan markalarla daha güçlü ve duygusal bir bağ kurabilmektedirler (Hudson, Roth, Madden ve Hudson, 2015). Farklı çalışmalar (Laroche vd., 2013; Erdoğmuş ve Çiçek, 2012), sosyal medya pazarlaması stratejilerinin (ör. sosyal medyada yer alan satış artırıcı çabalar, paylaşım içeriği, içeriğin popülerliği ve diğer sosyal medya platformlarında paylaşımı) tüketici marka sadakati üzerine olumlu etkilerini de saptamışlardır. Yine Erdoğmuş ve Çiçek'in (2012) çalışmasında, sosyal medya pazarlamasının marka imajı üzerine etkileri de saptanmıştır. Benzer şekilde Seo ve Park (2018) da çalışmalarında, sosyal medya pazarlaması faaliyetlerinin tüketicinin marka farkındalığı ve marka imajı üzerinde olumlu etkilerini desteklemişlerdir. Literatürde yer alan farklı çalışmalar da sosyal medya pazarlaması uygulamalarının marka değerini oluşturan faktörler (Kim ve Ko, 2012; Yadav ve Rahman, 2017; İsmail (2017), marka bilinci (İsmail, 2017), markaya yönelik tutumları (Inoue vd., 2016) olumlu yönde etkilediği saptanmıştır.

İtibar üzerine yapılan çalışmalarda ise tartışmalı sonuçlara rastlamak mümkündür. Bir grup çalışmada (Kim ve Ko, 2012; Tuten, 2008), olumlu algılanan sosyal medya uygulamalarının, marka itibarını artırabileceği yönünde sonuçlara ulaşılmıştır. Ancak bazı araştırmacılar (ör. Dijkmans vd., 2015), sosyal medya

\footnotetext{
${ }^{3}$ Sosyal medya alanında, elektronik ortamda oluşturulmuş ilk kulaktan kulağa iletişim ajansı olarak 2000 yılından beri dünya çapında hizmet vermektedir. Daha fazla bilgi için bakınız: "http://www.deiworldwide.com/".
} 
kanallarını aktif olarak kullanmanın işletmelere itibar açısından dezavantajları da bulunabileceğini ifade etmişlerdir. Bunun nedeni olarak, sosyal medya platformlarının tek yönlü olmayan, tüketici katılımının çoğu zaman kontrol altında tutulamadığı ve itibarı zedeleyebilecek riskleri beraberinde getirebilen mecralar olması gösterilmiştir (Aula, 2010). Sosyal medyada kullanıcılar ürün ya da marka hakkındaki görüşlerini özgürce paylaşabilmektedirler. Kullanıcıların bu paylaşımları, zaman zaman işletmelere operasyonel, etik veya müşteri memnuniyeti anlaminda zarar verebilmektedir (Tripp ve Gregoire, 2011). Örneğin, ürün kalitesi nedeni ile tek bir tatmin olmamış müşteri dahi sosyal medya kanalları üzerinden yayınlayacağı markaya ilişkin beyanlar ile söz konusu işletmenin itibarını olumsuz yönde etkileyebilecektir (Dijkmans vd., 2015).

Tüm bu tartışmalar ışığında sosyal medya bir işletmenin kurumsal iletişimi içerisindeki önemli ögelerden biri haline gelmiştir. Bu bağlamda, yalnızca sosyal medya araçlarının doğru kullanımı, itibarı olumlu yönde etkileyeceği ifade edilmiştir (Floreddu vd., 2014). Dolayısıyla, tüketicinin markalara ilişkin sosyal medya algılarının ölçümü oldukça değerli olabilecektir. Sosyal medya pazarlaması algısı 5 boyuttan oluşan kavramsal bir yapıdır. Buna göre; Eğlence boyutu, söz konusu markanın sosyal medya aktivitelerinden keyif almayı ve eğlenmeyi; Etkileşim boyutu, söz konusu markanın sosyal medya hesabını kullananlar arasındaki etkileşimi, bilgi paylaşımını ve fikir alışverişini; Ĕgilim boyutu, markanın sosyal medyasının yeni gelişmelere uyum sağlamasını; Özelleştirme boyutu, markanın sosyal medya hesabının kişiye özel, özelleştirilmiş bilgi ve içerik sunabilmesini; son olarak Kulaktan Kulağa İletişim boyutu ise, markanın sosyal medya kullanıcılarının edindikleri bilgiyi diğerlerine sosyal medya hesabı aracılığıyla iletme, yayma eğilimini ifade etmektedir (Kim ve Ko, 2012).

\subsection{Kurumsal İtibar Algısı ve Kurumsal İtibarın Kişiselleştirme Metaforu ile Ölçümü}

En geniş tanımı ile kurumsal itibar, paydaşların süreç içerisinde işletmeyle ilgili sahip oldukları genel değerlendirmeleridir (Gotsi ve Wilson, 2001). Bu değerlendirmeler; paydaşların işletme ile yaşadıkları deneyimlere, işletme ile ilgili bilgi sağlayan herhangi bir iletişime veya işletmenin rakipleri ile yapılan kıyaslamaya dayanmaktadır (Gotsi ve Wilson, 2001). Genel olarak kabul edilmiş tanımlardan bir diğerine göre kurumsal itibar, bir işletmenin geçmiş faaliyetlerinin sonuçlarıdır (Nguyen ve Leblanc, 2001). Tüm bu tanımlara göre, kurumsal itibar tüketicinin zihninde oluşmaktadır ve bu çalışmada ölçülen de tüketicinin kurumsal itibar algısıdır. $\mathrm{Bu}$ nedenle çalışmada kurumsal itibar algısı üzerinde durulmaktadir.

Pazarlama bakış açısıyla ele alındığında kurumsal itibar algısının tüketici davranışları üzerinde önemli etkileri olduğu görülmüştür. Birçok farklı çalışma, kurumsal itibar algısının işletmenin satışlarının ve pazar payının artması üzerinde olumlu etkisi olduğunu ortaya koymuştur (ör. Shapiro, 1982). Satışların ve pazar 
payının artmasının yanı sıra, kurumsal itibar arttıkça müşterilerin o işletme ile uzun dönemli ilişki kurma eğilimleri de artabilmektedir (Andreassen ve Lindestad, 1998; Robertson, 1993; Yoon vd., 1993). Ostrowski (1993) de çalışmasında, kurumsal itibar ve müşteri sadakati arasında anlamlı ve olumlu bir etki olduğunu ortaya koymuştur. Dolayısıyla olumlu algılanan bir kurum itibarı, müşteri açısından değerli çıktılar yaratabilmektedir (Bennett ve Gabriel, 2001).

Kurumsal itibar işletmelere bir yandan bu denli fayda yaratırken, diğer taraftan ölçümü tartışmalara konu olmuştur. Nasıl ölçülebileceği ile ilgili birçok yaklaşım ortaya konmuş ve bu yaklaşımlar eleştirilere maruz kalmıştır (MacMillan vd., 2005). Davies vd. (2001) de literatürde mevcut kurumsal itibar algisının ölçeklerinin kapsayıcı olmaması, herhangi bir alanda geçerli olan boyutlarının başka bir alanda geçerli olamaması ve imaj ile kimlik kavramlarını aynı anda ele almıyor olması nedeniyle ölçüm yöntemlerini eleştirmiş, çalışmalarında kurumsal itibar algısının ölçümünde kişiselleştirme metaforu kullanımını ilk olarak kavramsallaştırmışlardır.

Postmodern tüketinin davranışı değişmekte; bütün yerine parçaya odaklanan daha bireysel ve içe dönük yaşamları tercih eden, gerçeklik yerine sembolleri (markalar tarafindan yaratılan imaj, kimlik ve algı), dikkate alan bireyler olarak karşımıza çıkmaktadırlar (Fırat ve Venkatesh, 1996). Bunlara ek olarak günümüzde tüketiciler, kendi sembolik kimlikleri ile markaların sembolik kimlikleri arasında ilişki kurmaya ve bu sembolleri anlamlandırmaya çalışmaktadır (Odabaşı, 2004: 102). $\mathrm{Bu}$ sebeple, metafor tüketicinin davranışlarını ve tercihlerini anlamlandırmada önemli bir araç olabilmektedir. Davies vd. (2001) bu nedenler 1şı̆̆ında kurumsal itibar algısı ölçümünde kişiselleştirme metaforu kullanımını kavramsallaştırmışlardır. Literatürdeki mevcut kurumsal itibar algısı ölçeklerinin kapsayıcı olmaması, boyutların her alanda geçerli olamaması gibi konuları da eleştirmişlerdir. Dolayısıyla geliştirdikleri yaklaşım ve ölçeğin, işletmenin tüm paydaşlarına ve sektör fark etmeksizin tüm markalara uygulanabileceğini savunmuşlardır. $\mathrm{Bu}$ çalışmada da- kurumsal itibar algısının ölçümlenmesinde metafor kullanımı benimsenmiştir. Nitekim literatürde metafor kullanımı ile, insanların marka gibi karmaşık bir yapıları daha iyi anlamlandırdığ 1 ifade edilmiştir. Böylece markanın ne olduğu anlaşılabilmekte ve farklı metaforlardan marka ile ilgili farklı bakış açıları edinilebilmektedir (Davies ve Chun, 2003). Kişiselleştirme metaforu; bir işletmeyi bir birey ile denk tutarak değerlendirir ve aşina olunan bir şeye atıfta bulunarak, karmaşık yapının anlaşılmasına katkıda bulunan bir yöntemdir (Morgan, 1983). Dolayısıyla, kişiselleştirme metaforunu araştırmalarında kullanan yaklaşımlar, genel olarak kurumu ya da markayı bir "birey" gibi değerlendirerek, sahip olabileceği "kişilik özellikleri”" üzerinden farklı paydaşların algılarını ölçmektedir (Davies, Chun, da Silva ve Roper, 2004). Aaker (1997) ise çalışmasında, marka kişiliğini "Marka ile bağdaştırılan bir dizi karakteristik insan özelliği”" şeklinde tanımlamıştır. Bu doğrultuda Davies vd. (2001), Aaker (1997)'in marka kişiliğini ölçmek üzere geliştirdiği "marka kişilik 
ölçeğini" uyarlayarak "kişiselleştirme metaforu ölçeğini”" ortaya koymuş ve kapsamlı bir ölçüm aracı oluşturmuşlardır. Bu doğrultuda Davies vd. (2001), Aaker'in (1997) bireylere özgü kişilik özelliklerini tanımlayan, Beş Faktör Kişilik Özellikleri (Big Five)'nden faydalanarak yedi boyutlu bir kurumsal itibar ölçeği ortaya koymuş (Berens, 2004) ve kişiselleştirme metaforu kullanımını kavramsallaştırmışlardır. Buna göre; Hoşluk boyutu, marka literatüründe güven, itibar literatüründe de sosyal sorumluluk kavramlarına karş1lık gelmekte ve kurumsal kişiliğin temel özelliklerinden biridir. Ölçekte yer alan Acımasızlık boyutu, olumsuz anlama sahip tek boyuttur. Bu boyut genel olarak bencil, kontrolcü, otoriter ve kibirli gibi kişilik sıfatlarını içeren bir boyuttur (Davies vd., 2004). Girişimcilik boyutu, kişilik literatüründe dişa dönüklük anlamına gelmektedir. Girişimcilik skoru yüksek olan işletmeler yenilikçi, heyecanlı, genç ve modern algılanırlar. Aaker (1997)'in marka kişiliği ölçeğinde de aynı isimle yer alan yetkinlik boyutu, işletmelerin kurumsal itibarını yönetirken göz önünde bulundurması gereken bir kavramdır. Şıklık boyutu, marka kişiliği ölçeğindeki (Aaker, 1997) kültür boyutu ile bağdaşmaktadır. Kurumsal literatürde ise daha çok itibar kavramına işaret etmekte ve moda gibi özellikli sektörlerde göreceli olarak daha yüksek skor elde edilebilmektedir. Kuvvetlilik boyutu marka kişiliği ölçeğindeki kullanımına paralel olarak, kurumsal kişiliğin cinsiyet boyutu olarak tanımlanmaktadır. Çalışanlar ve müşteriler arasında görece sert bir iletişim tarzına işaret etmekte, örneğin inşaat sektöründe oldukça yüksek olduğu ortaya konulmaktadır. Ulaşılabilirlik boyutu, kurum içerisinde kullanılan çalışanların giyimi, müşteri ile iletişimleri gibi konularda resmi olmamayı ifade etmektedir (Davies vd., 2004).

\subsection{Alg1lanan Sosyal Medya Faaliyetlerinin Kurumsal İtibar Alg1s1 Üzerine Etkileri}

Sosyal medya uygulamalarının artması ile birlikte, bu uygulamaların sonuçlarını ölçmeden örgütsel hedeflere ulaşmak ve bir marka değeri yaratmak işletmeler açısından zorlaşmıştır (Culnan vd., 2010). Çevrimiçi ekosistemde arama motoru sıralamalarının öneminin artmasına paralel olarak itibar yönetimi alanında sosyal medyanın etkisinin de arttığı, sosyal medyanın itibar yönetimine farklı alanlarda katkı sağladığı, örneğin sosyal medya sitelerinin arama motorlarında görünür olması ve listelenmesinin işletme için değerli bir kazanım olacağı ifade edilmiştir. Bunun yanı sıra, sosyal medya aracılığı ile işletmenin ya da markanın desteklenip öne çıkarılabileceği, arama motorlarında listelenen her olumlu görünümün ya da sosyal medya aracılığıyla oluşturulmuş olumlu içeriklerin, olumsuz haber ve içeriklerin daha aşağıda listelenmesine de katkı sağlayacağının altı çizilmiştir. Bunun da ötesinde, işletmelerin sosyal medyayı -izleme araçlarını doğru kullanarak- haklarında çıkan her olumsuz haberi güçlü pazarlama mesajlarına çevirebilmek adına bir firsat olarak kullanabilecekleri ifade edilmiştir (Weinberg, 2009, 27). Bu ilişki ise literatürde yer alan işaret teorisine dayandırılabilecektir. İşaret teorisine göre tüketiciler tercih yapacakları zaman ve asimetrik bilgi sahibi 
olduklarında birtakım işaretlere göre karar vermektedirler (Boateng, 2019). Son zamanlarda firmalar tüketicilerinin algı ve davranışlarını etkilemek için dijital uygulamalar ile işaret yollamaktadırlar (Benlian ve Hess, 2011). Daha şeffaf ve güvenli bir iletişim kurmak için sosyal medya araçları, sıkça sorulan sorular gibi dijital uygulamalar da hem müşteri ilişkilerini iyileştirmekte ve buna bağlı olarak da itibarı artırabilmektedir (Benlian ve Hess, 2011). Dijkmans ve diğeleri (2015) çalışmalarında, müşterilerin kurumların sosyal medya aktiviteleri ile olan etkileşimleri (işletmenin sosyal medyası ile ilgili ne kadar bilgi sahibi olduğu ve ne yoğunlukta takip ettiği) ve algıladıkları kurumsal itibar arasında olumlu bir ilişki olduğunu ortaya koymuşlardır. Farklı bir çalışma da (Çiftçi, İşler, Çiftçi ve Yarangümelioğlu, 2015), kurumsal itibarı oluşturan bir dizi çalışmanın (sosyal sorumluluk projeleri, kurumsal imaj çalışmaları, kamuoyu ile ilişki yönetimi vb.) sosyal medyada görünür hale gelmesi gerektiği savunulmuş, böylelikle sosyal medyanın, kurumsal itibar algısına katkı sağlayabileceği vurgulanmıştır.

Gerçekleştirilen literatür taraması ışığında çalışmada, sosyal medya algısının boyutlarının kişiselleştirme metaforu yaklaşımıyla ölçülen kurumsal itibar algısı boyutları üzerine etkilerini ölçmeye yönelik bir araştırma modeli önerisi sunulmaktadır (Şekil-1). Söz konusu model önerisinin araştırma soruları şu şekilde belirlenmiştir:

AS1: Tüketicinin sosyal medya algısının kişiselleştirme metaforu yaklaşımı ile ölçülen kurumsal itibar algısı üzerine anlamlı ve olumlu bir etkisi var mıdır?

AS2: Tüketicinin sosyal medyada algısının boyutlarının (Eğlence, Etkileşim, Eğilim, Özelleştirme ve Kulaktan Kulağa İletişim); kurumsal itibar boyutları (Hoşluk, Girişimcilik, Yetkinlik, Şıklık, Kuvvetlilik, Ulaşılabilirlik) üzerine olumlu, yalnızca Acımasızlık boyutu üzerine olumsuz bir etkisi var mıdır? 


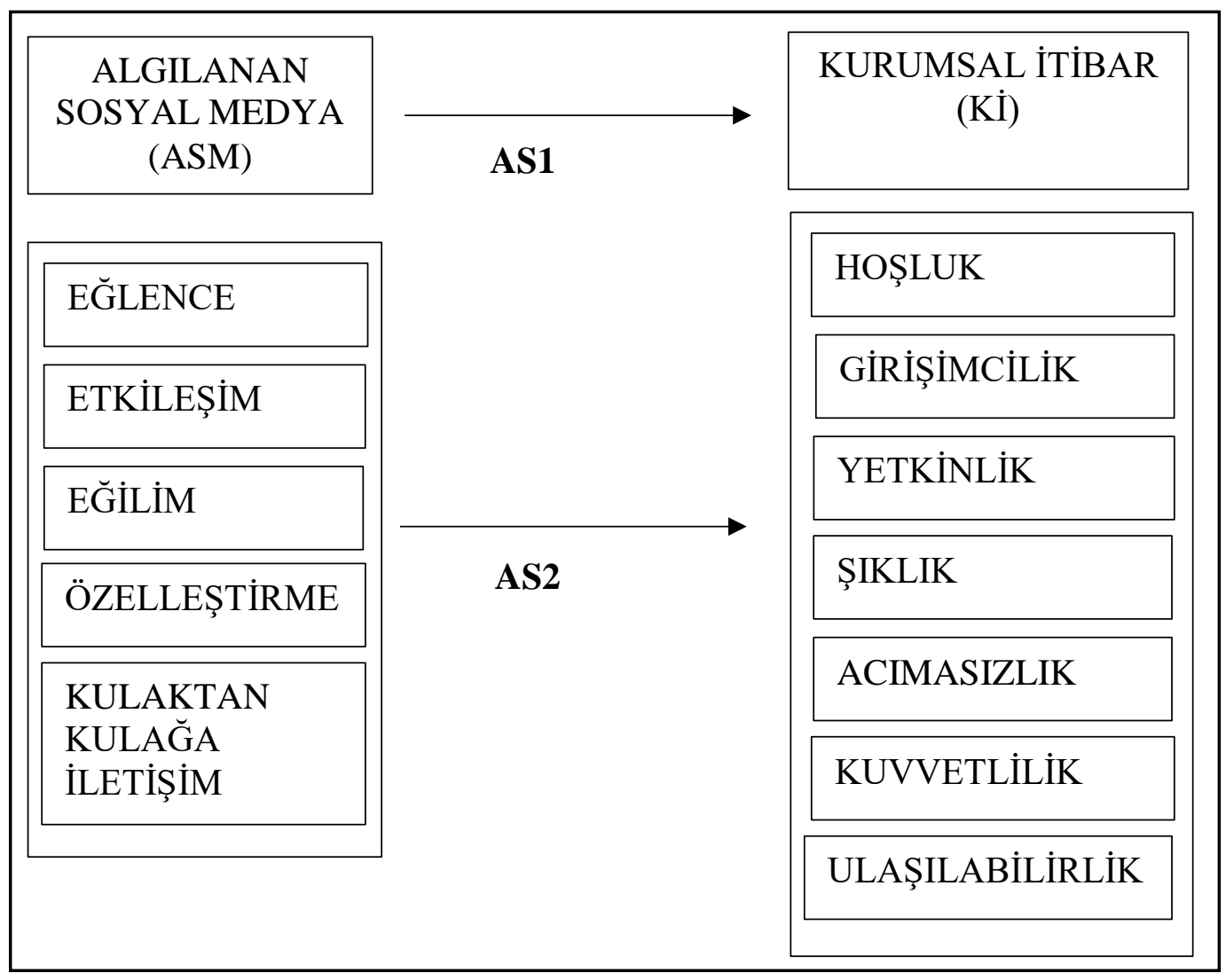

Şekil -1 Çalışmanın Modeli

\section{Araştırma Metodolojisi}

\subsection{Araştırmada Kullanılan Ölçekler}

Çalışmada yer alan algılanan sosyal medya ölçeği Kim ve Ko (2012)'nun çalışmalarından alınmıştır. Kim ve Ko (2012) çalışmalarında 11 soru ve 5 boyut ile sosyal medya algısını ölçmüştür. Bu çalışmada da tüketicinin sosyal medya

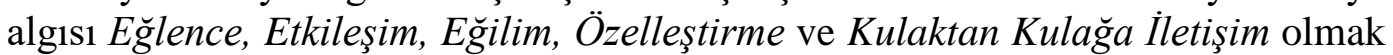
üzere 5 boyutta değerlendirilecektir. Çalışmada yer alan kurumsal itibar ölçeği Davies, ve diğelerinin (2004) çalışmasından alınmıştır. Davies vd. (2004), kurumsal kişilik ölçeği doğrultusunda belirledikleri 7 boyut ve 49 ifade ile kurumsal itibarı ölçmektedirler. Bu boyutlar; Hoşluk, Acımasızlık, Girişimcilik, Yetkinlik, Şıklık, Kuvvetlilik ve Ulaşılabilirlik boyutudur (Davies vd., 2004). İlgili ölçek maddeleri "Kesinlikle Katılmıyorum"dan "Kesinlikle Katılıyorum"a kadar sıralanan 5'li Likert Tipi ölçeğiyle ölçülmektedir.

\subsection{Evren, Örneklem ve Veri Toplama}

$\mathrm{Bu}$ araştırmanın evrenini, Türkiye'deki sosyal medya kullanıcılarından, Ankara ilinde bulunan Panora AVM işletmesinin sosyal medya hesabını takip eden 
kullanıcılar oluşturmaktadır. Örneklem hacmine karar verilirken, basit doğrusal regresyon ve çoklu doğrusal regresyon analizleri ile ilerleneceği göz önünde bulundurularak, temel bir formül (Tabachnick ve Fidell, 2013, 123) doğrultusunda katılım alt sınırı belirlenmiştir:

$\mathrm{N} \geq 50+8 \mathrm{~m}$

$\mathrm{N}=$ Örneklem hacmi,

$\mathrm{m}=$ Bağımsız değişkenlerin sayısı

Örneklem seçme yöntemi olarak olasılıklı olmayan örneklem seçme yöntemlerinden, kolayda örneklem seçim tekniği kullanılmıştır. Bunun sebebi, Türkiye'deki sosyal medya kullanıcıları veya Panora AVM'nin sosyal medya takipçileri şeklinde bir listeye ulaşılamamış olmasıdır. Formüldeki m değeri bağımsız değişken sayısını temsil etmektedir. Kantitatif araştırma yönteminde örneklem hacmi hesaplamasının, cevabı aranan her bir soru ya da soru kategorisine göre yapılması önerilmiştir (Kavak, 2013, 227). Bu çalışmada da soru kategorileri boyutlara karşıllk gelmektedir. Nitekim, algılanan sosyal medya ölçeğinin boyutları aynı zamanda çalışmanın bağımsız değişkenleridir. Çalışmanın bağımsız değişkenlerinin beş alt boyut ve bir adet genel sosyal medya algısından oluşması dolayısıyla örneklem hacminin minimum değeri 98 olarak belirlenmiştir. Öte yandan, etkin bir tahminin temelini oluşturan önemli ögelerden birinin örneklem büyüklügü olmasından yola çıkarak, kısıtlı zamanda en yüksek sayıda soru kâğıdı toplanması hedeflenmiş ve örneklem hacmi 250 olarak belirlenmiştir. Veriler 2018 yılı Kasım ayı boyunca toplanmıştır.

\section{Bulgular ve Tartışma}

\subsection{Katılımcılara İlişkin Bilgiler}

Anket formunda örneklemin özelliklerini görebilmek ve demografik bilgilerine ulaşmak amacıyla hazırlanmış ifadelere de yer verilmiştir. Bu sorular katılımcıların cinsiyetini, yaşını, eğitim düzeyini ve ilgili markanın hangi sosyal medya kanallarını takip ettiklerini öğrenmeye yönelik olarak hazırlanmıştır. Buna göre katılımcıların \% 44,8'i kadındır. \% 69,2'si 25-34 yaş aralığındadır ve \% 88'i üniversite mezunudur. Katılımcıların, araştırmada referans noktası olarak belirlenen marka olan Panora AVM'yi hangi sosyal medya kanallarından takip ettikleri ile ilgili veriler incelendiğinde; \% 76,3'ünün markayı Instagram üzerinden takip ettiği görülmüştür.

\subsection{Verilerin Ön Testi}

Çalışmanın hipotezlerinin test edilmesinden önce 54 katılımcıdan toplanan veri ile ön test yapılmıştır ve güvenilirlik analizi uygulanmıştır. Cronbach Alfa katsayıları ve düzeltilmiş madde toplam korelasyonları değerlendirilerek yapılan güvenilirlik analizinde, algılanan sosyal medya ölçeği içerisinde yer alan 5 boyuttan Eğilim, 
Özelleştirme, Kulaktan Kulağa İletişim boyutları ve kurumsal kişilik ölçeği içerisinde yer alan 7 boyuttan, Kuvvetlilik ve Ulaşılabilirlik boyutları haricinde kalan tüm boyutlarda; alfa değerlerinin önerildiği gibi (Hair vd., 2010:125) 0,70'in üzerinde olması dolayısıyla ölçekler güvenilir bulunmuştur. Ölçeklerde yer alan tüm ifadelerin düzeltilmiş madde toplam korelasyonu değerlerinin 0,52 ile 0,26 arasında değiştiği görülmektedir. $\mathrm{Bu}$ doğrultuda, hem alfa katsayıları düşük çıkan boyutlarda, hem de alfa katsayısı yüksek olan ve ölçeğin güvenilirliğinin doğrulandığı boyutlarda birtakım değişiklikler yapılmıştır.

Ölçek güvenilir bulunmasına rağmen ifadelerde düzenleme yapma gerekliliği doğmasının sebepleri; veri toplama esnasında gelen katılımcı geri bildirimleriyle yeterince açık-anlaşılır olmadığı belirlenen veya analiz çıktılarının, güvenilirliği arttırmak adına silinmesini önerdiği ifadeler bulunmasıdır. Örneğin, "Şıklık" boyutu içerisinde yer alan "Snop" ifadesi, kullanıcılar tarafindan yeterince anlaşılmamıştır. Ön test çerçevesinde yapılan güvenilirlik analizi sonucunda istatistiksel olarak da bu tespitin doğrulanmasıyla, Snop ifadesinin soru kağıdından çıkarılmasına karar verilmiştir.

Araştırmada kullanılan ölçeklerde yer alan maddelerin boyutlarına ayrıldıklarını tespit etmek amacı ile keşifsel faktör analizleri yapılmıştır. Analizlerde temel bileşenler (principal components) yöntemi uygulanmış, değişkenlerin faktör analizine uygunluğunun test edilmesinde Kaiser-Meger-Olkin (KMO) katsayısı kullanılmıştır. KMO değerlerinin tamamı $\geq 0,50$ olup, p değerleri 0,05 'ten küçüktür $(0,000)$. Her bir boyutta yer alan ifadelerin faktör yükleri 0,50 'den büyüktür. Kurumsal kişilik ölçeğinin boyutlarına ayrı ayrı uygulanan keşifsel faktör analizi sonuçlarına göre; KMO değerlerinin tamamı $\geq 0,50$ olup, $\mathrm{p}$ değerleri 0,05 'ten küçüktür $(0,000)$. Her bir boyutta yer alan ifadelerin faktör yükleri 0,50 'den büyüktür.

\subsection{Verilerin Analizi ve Bulgular}

Anket formunda bulunan ölçeklerin güvenilirliklerinin test edilmesi amaciyla, ön testte de olduğu gibi ölçeklerin Cronbach Alfa değerlerine ve düzeltilmiş madde toplam korelasyonlarına bakılmıştır (Tablo-1). 
Tablo 1. Sosyal Medya Algısı Boyutlarına Yönelik Güvenilirlik Analizi Sonuçları

İfadeler

Güvenilirlik (Cronbach Alpha)

Cevapların

Bağımsızlık Kontrolü

Ölçek

Düzeltilmiş

Ki-Kare P*

Toplam

Korelasyonu

\begin{tabular}{|c|c|c|c|c|}
\hline Ĕglence Boyutu & 0,84 & & & \\
\hline ALGI1 & & 0,643 & 170,24 & 0,000 \\
\hline ALGI2 & & 0,612 & 170,64 & 0,000 \\
\hline ALGI3 & & 0,621 & 137,8 & 0,000 \\
\hline Etkileșim Boyutu & $\mathbf{0 , 8 4}$ & & & \\
\hline ALGI4 & & 0,645 & 133,24 & 0,000 \\
\hline ALGI5 & & 0,655 & 163,36 & 0,000 \\
\hline Ĕgilim Boyutu & 0,84 & & & \\
\hline ALGI6 & & 0,557 & 112,68 & 0,000 \\
\hline ALGI7 & & 0,557 & 152,00 & 0,000 \\
\hline \multicolumn{5}{|l|}{ Özelleştirme Boyutu } \\
\hline ALGI8 & & & 184,56 & 0,000 \\
\hline $\begin{array}{l}\text { Kulaktan Kulağa İletişim } \\
\text { Boyutu }\end{array}$ & $\mathbf{0 , 8 4}$ & & & \\
\hline ALGI9 & & 0,658 & 127,72 & 0,000 \\
\hline ALGI10 & & 0,548 & 100,16 & 0,000 \\
\hline
\end{tabular}

Buna göre algilanan sosyal medya ölçeğinde yer alan 5 boyuttan 1'inin ve kurumsal kişilik ölçeğinde yer alan 7 boyuttan 5'inin Cronbach Alfa değeri Hair vd. (2010, 125) tarafından önerildiği gibi 0,70 'in üzerindedir, dolayısıyla ölçeklerin güvenilir olduğu anlaşılmaktadır (Tablo-2). 0,70'ten daha küçük Cronbach Alfa değerleri alan, kurumsal kişilik ölçeğinin Kuvvetlilik ve Ulaşılabilirlik boyutları değerlendirilirken, 0,6'dan küçük Cronbach Alfa değerinin kabul edilebilir olduğu, fakat güçlü bir güvenilirlik ifade etmediği (George ve Mallery, 2003) bilgisine dayandırılmıştır. Algılanan sosyal medya ölçeği içerisinde yer alan Özelleştirme boyutu ise, ön testin ardından tek soruya indirgenmesi dolayısıyla güvenilirliği test edilmeksizin bağımsız değişkenlerden biri olarak kabul edilmiştir. 
Tablo 2. Kurumsal İtibar Boyutlarına Yönelik Güvenilirlik Analizi Sonuçları

\begin{tabular}{|c|c|c|c|c|}
\hline \multirow[t]{2}{*}{ İfadeler } & \multicolumn{2}{|c|}{ Güvenilirlik (Cronbach Alpha) } & \multicolumn{2}{|c|}{$\begin{array}{c}\text { Cevapların } \\
\text { Bağımsızlı̆̆ (Ki- } \\
\text { Kare) }\end{array}$} \\
\hline & Ölçek & $\begin{array}{l}\text { Düzeltilmiş } \\
\text { Madde } \\
\text { Toplam } \\
\text { Korelasyonu }\end{array}$ & Ki-Kare & $\mathbf{P}^{*}$ \\
\hline Hoşluk & $\mathbf{0 , 9 3}$ & & & \\
\hline Arkadaş Canlısı & & 0,685 & 196,68 & 0,000 \\
\hline Cana Yakın & & 0,696 & 166,36 & 0,000 \\
\hline Açık & & 0,673 & 142,16 & 0,000 \\
\hline Dobra & & 0,506 & 146,80 & 0,000 \\
\hline Duyarlı & & 0,726 & 145,48 & 0,000 \\
\hline Rahatlatıcı & & 0,741 & 151,16 & 0,000 \\
\hline Destekleyici & & 0,720 & 156,24 & 0,000 \\
\hline Uzlaşmacı & & 0,692 & 150,16 & 0,000 \\
\hline Dürüst & & 0,752 & 145,64 & 0,000 \\
\hline Samimi & & 0,740 & 143,12 & 0,000 \\
\hline Güvenilir & & 0,732 & 129,48 & 0,000 \\
\hline $\begin{array}{l}\text { Sosyal Sorumluluk Bilincine } \\
\text { Sahip }\end{array}$ & & 0,708 & 188,32 & 0,000 \\
\hline Girişimcilik & $\mathbf{0 , 8 8}$ & & & \\
\hline Karizmatik & & 0,526 & 164,44 & 0,000 \\
\hline Modayı Takip Eden & & 0,653 & 146,84 & 0,000 \\
\hline Genç & & 0,682 & 122,00 & 0,000 \\
\hline Hayal Gücü Geniş & & 0,670 & 168,32 & 0,000 \\
\hline Modern & & 0,707 & 130,32 & 0,000 \\
\hline Heyecan Verici & & 0,653 & 140,92 & 0,000 \\
\hline Yenilikçi & & 0,736 & 142,28 & 0,000 \\
\hline Dişa Dönük & & 0,559 & 141,64 & 0,000 \\
\hline Cesur & & 0,584 & 156,12 & 0,000 \\
\hline Yetkinlik & $\mathbf{0 , 8 8}$ & & & \\
\hline Güvenilir & & 0,601 & 157,32 & 0,000 \\
\hline Kendinden Emin & & 0,763 & 166,52 & 0,000 \\
\hline Çalışkan & & 0,709 & 136,44 & 0,000 \\
\hline İstekli & & 0,756 & 146,32 & 0,000 \\
\hline Başarı Odaklı & & 0,722 & 124,32 & 0,000 \\
\hline Öncü & & 0,635 & 98,68 & 0,000 \\
\hline Kurumsal & & 0,537 & 142,72 & 0,000 \\
\hline
\end{tabular}


Tablo 2. Kurumsal İtibar Boyutlarına Yönelik Güvenilirlik Analizi Sonuçları (Devamı)

\begin{tabular}{lcccc}
\hline Şıklık & $\mathbf{0 , 8 6}$ & & & \\
\hline Çekici & & 0,719 & 127,48 & 0,000 \\
Stil Sahibi & & 0,670 & 124,28 & 0,000 \\
Zarif & & 0,728 & 123,92 & 0,000 \\
Prestijli & 0,653 & 136,52 & 0,000 \\
Benzersiz & 0,516 & 95,00 & 0,000 \\
İnce Ruhlu & 0,640 & 133,28 & 0,000 \\
Elit & $\mathbf{0 , 7 6}$ & 0,510 & 133,12 & 0,000 \\
\hline Acımasızlık & & & \\
\hline Kibirli & & 0,557 & 41,52 & 0,000 \\
Saldırgan & 0,358 & 125,16 & 0,000 \\
Bencil & & 0,618 & 19,080 & 0,000 \\
İçe Dönük & 0,529 & 44,20 & 0,000 \\
Otoriter & 0,543 & 93,56 & 0,000 \\
Kontrolü Elinde Bulunduran & & 0,458 & 97,00 & 0,000 \\
\hline Kuvvetlilik & $\mathbf{0 , 5 8}$ & 0,460 & 136,68 & 0,000 \\
\hline Mücadeleci & & 0,479 & 147,32 & 0,000 \\
Dayanıklı & 0,263 & 94,720 & 0,000 \\
Sert & & & \\
\hline Ulaşılabilirlik & $\mathbf{3}$ & \\
\hline Gayrıresmi & 0,370 & 46,40 & 0,000 \\
Mütevazı & 0,432 & 109,92 & 0,000 \\
Kolay Ulaşılır & 0,285 & 142,48 & 0,000 \\
\hline
\end{tabular}

$* \mathbf{P}<0.05$

Araştırmada kullanılan ölçeklerde yer alan maddelerin boyutlarına ayrıldıklarını tespit etmek amacı ile kesifsel faktör analizleri yapılmıştır. Analizlerde temel bileşenler (principal components) yöntemi uygulanmış, değişkenlerin faktör analizine uygunluğunun test edilmesinde Kaiser-Meger-Olkin (KMO) katsayıs1 kullanılmıştır. Bu bağlamda algılanan sosyal medya ölçeğinin boyutlarına ayrı ayrı uygulanan keşifsel faktör analizinde KMO değerlerinin tamamı $\geq 0,50$ olup, p değerleri 0,05 'ten küçüktür $(0,000)$. Her bir boyutta yer alan ifadelerin faktör yükleri 0,50 'den büyüktür. Kurumsal kişilik ölçeğinin boyutlarına ayrı ayrı uygulanan keşifsel faktör analizinde KMO değerlerinin tamamı $\geq 0,50$ olup, $\mathrm{p}$ değerleri 0,05 'ten küçüktür $(0,000)$. Her bir boyutta yer alan ifadelerin faktör yükleri 0,50 'den büyüktür. 


\subsection{Araştırmanın Model Önerisinin Test Edilmesi}

Araştırma amaçları doğrultusunda önerilen modelde yer alan araştırma soruları içerisindeki ilişkilerin testi için, SPSS 23 programında Basit Doğrusal Regresyon Analizi ve Çoklu Doğrusal Regresyon Analizi kullanılmıştır. Bu bağlamda, Panora AVM markası için, tüketicinin sosyal medya algısının kurumsal itibar üzerindeki etkisi basit doğrusal regresyon analiziyle test edilirken, Panora AVM markası için, tüketicinin sosyal medya algısını oluşturan 5 boyutun, algıladığı kurumsal itibarın 7 boyutu üzerindeki etkisi ise çoklu doğrusal regresyon analiziyle test edilmiştir.

Tablo 3. Algılanan Sosyal Medyanın Kurumsal İtibar Algısı Üzerindeki Etkisine İlişkin Regresyon Analizi

\begin{tabular}{|c|c|c|c|c|c|c|}
\hline AS1 & Tolerans & VIF & $\overline{\mathbf{R}^{2}}$ & $\mathbf{F}$ & Beta & $\mathbf{P}$ \\
\hline Model & 1,00 & 1,00 & 0,48 & 232,79 & & \\
\hline Sabit & & & & & 1,49 & $0,00^{*}$ \\
\hline Sosyal Medya Algısı & & & & & 0,69 & $0,00 *$ \\
\hline
\end{tabular}

Bağımlı Değişken: Kurumsal İtibar, ${ }^{*} \mathrm{p} \leq .05$

Yapılan regresyon analizine göre, tüketicinin sosyal medya algısının, kurumsal itibar algısını olumlu $(\beta=0,696)$ yönde etkilemesi istatistiksel olarak anlamlı ( $<<0,01)$ bulunmuştur. Dolayısıyla araştırma sorusu 1 (AS1) desteklenmektedir. Buna göre tüketicinin kurumsal itibar algısının anlamlı bir kısmı (\%48), sosyal medyaya ilişkin algıları ile açıklanabilmektedir (Tablo-3). Diğer taraftan VIF değerinin 10'dan düşük olması (Durmuş vd., 2016:156), çoklu bağlantı probleminin olmadığını göstermektedir. Buna ilişkin olarak Modelin anlamlı olduğu söylenebilecektir.

Çalışmanın ikinci araştırma sorusu, Panora AVM markası için, tüketicinin sosyal medya algısına ilişkin her bir boyutun (Eğlence, Etkileşim, Eğilim, Özelleştirme ve Kulaktan Kulağa İletişim) kurumsal itibarın her bir boyutu (Hoşluk, Girişimcilik, Yetkinlik, Şıklık, Kuvvetlilik, Ulaşılabilirlik, Acımasızlık) üzerine etkilerini incelemek üzere oluşturulmuştur. Söz konusu boyutlara arasındaki ilişkileri ölçmeye yönelik olarak çoklu regresyon analizinden faydalanılmıştır. Buna göre, ilk çoklu regresyon analizinin bağıml değişkeni kurumsal itibar ölçeğinde yer alan hoşluk boyutu, bağımsız değişkenler ise algılanan sosyal medya boyutlarıdır (Tablo 2). 
Tablo 4. Algılanan Sosyal Medya Boyutlarının Kurumsal İtibarda Hoşluk Boyutu Üzerindeki Etkisine İlişkin Çoklu Doğrusal Regresyon Analizi

\begin{tabular}{lccccccc}
\hline AS2 & $\mathbf{R}^{2}$ adj & $\mathbf{R}^{2}$ & $\mathbf{F}$ & Beta & $\mathbf{P}$ & Tolerans & VIF \\
\hline Model & 0,473 & 0,483 & 45,632 & & & & \\
Eğlence & & & & 0,090 & 0,191 & 0,450 & 2,221 \\
Etkileşim & & & & 0,223 & $0,001 *$ & 0,462 & 2,162 \\
Eğilim & & & 0,259 & $0,000^{*}$ & 0,555 & 1,801 \\
Özelleştirme & & & 0,038 & 0,496 & 0,548 & 1,826 \\
Kulaktan Kulağa İletişim & & & & 0,238 & $0,000^{*}$ & 0,679 & 1,472 \\
\end{tabular}

Bağımlı Değişken: Kurumsal İtibarda Hoşluk Boyutu, *p $\leq .01$

Yapılan çoklu regresyon analizine göre (Tablo-4), tüketicinin Panora AVM'nin sosyal medyasına yönelik olarak algıladığı Etkileşim $(\beta=0,223 ; p<0,01)$, Eğilim $(\beta=0,259 ; \mathrm{p}<0,01)$, Kulaktan Kulağa İletişimin $(\beta=0,238 ; \mathrm{p}<0,01)$ kurumsal itibarın Hoşluk boyutu üzerine istatistiksel olarak anlamlı ve olumlu yönde etkisi bulunmuştur. Algılanan Eğlence ve Özelleştirmenin ise, Hoşluk boyutu üzerine anlamlı bir etkisi saptanamamıştır. Bunun yanı sıra, VIF değerleri incelendiğinde bağımsız değişkenler arasında çoklu doğrusallık problemi olmadığı görülmüştür. Buna göre, modelin anlamlı olduğu söylenebilecektir. Beta katsayılarına bakıldığında "Eğilim" boyutunun diğer boyutlara oranla Kurumsal İtibarın Hoşluk boyutunu daha fazla etkilediği söylenebilecektir. Buna göre Panora AVM, sosyal medya hesaplarında tüketicilerin birbirleri ile etkileşimini kolaylaştırdığında, tüketicilerin fikir alışverişinde bulunmalarını sağladığında, tüketiciye yeni bilgiler sunduğunda veya güncellemelerin kullanıcılar arasında kolaylıkla yayılmasına firsat verdiğinde tüketiciler tarafından daha arkadaş, canlısı, cana yakın veya samimi algılanabilecektir. Böylece tüketici tarafından algılanan kurumsal itibarları da yükselebilecektir. 
Tablo 5. Algılanan Sosyal Medya Boyutlarmın Kurumsal İtibarda Girişimcilik Boyutu Üzerindeki Etkisine İlişkin Çoklu Regresyon Analizi

\begin{tabular}{|c|c|c|c|c|c|c|c|}
\hline AS2 & $\mathbf{R}^{2} \mathbf{a d j}$ & $\mathbf{R}^{2}$ & $\mathbf{F}$ & Beta & $\mathbf{P}$ & Tolerans & VIF \\
\hline Model & 0,341 & 0,354 & 26,780 & & & & \\
\hline Eğlence & & & & 0,225 & $0,004 *$ & 0,450 & 2,221 \\
\hline Etkileşim & & & & 0,142 & $0,061 * *$ & 0,462 & 2,162 \\
\hline Ĕgilim & & & & 0,228 & $0,001 *$ & 0,555 & 1,801 \\
\hline Özelleştirme & & & & 0,070 & 0,264 & 0,548 & 1,826 \\
\hline Kulaktan Kulağa İletişim & & & & 0,059 & 0,393 & 0,679 & 1,472 \\
\hline
\end{tabular}

Bağımlı Değiş̧en: Kurumsal İtibarda Girişimcilik Boyutu, ${ }^{*} \mathrm{p} \leq .05,{ }^{* *} \mathrm{p} \leq .10$

Yapılan bir diğer çoklu regresyon analizinin bağımlı değişkeni kurumsal itibar ölçeğinde yer alan girişimcilik boyutu, bağımsız değişkenler ise algılanan sosyal medya boyutlarıdır (Tablo-5). Analiz sonuçlarına göre, tüketicinin Panora AVM'nin sosyal medyasına yönelik olarak algıladığı Eğlence $(\beta=0,225 ; p<0,05)$, Etkileşim $(\beta=0,142 ; p<0,05)$, Eğilimin $(\beta=0,228 ; p<0,01)$ kurumsal itibarın Girişimcilik boyutu üzerine istatistiksel olarak anlamlı $(\mathrm{p}<0,01)$ ve olumlu yönde etkisi bulunmuştur. Algılanan Özelleştirme ve Kulaktan Kulağa İletişimin ise, Girişimcilik boyutu üzerine anlamlı bir etkisi saptanamamıştır. Bunun yanı sıra, VIF değerleri incelendiğinde bağımsız değişkenler arasında çoklu doğrusallık problemi olmadığı görülmüştür. Beta katsayılarına bakıldığında "Eğilim" boyutunun diğer boyutlara oranla Kurumsal İtibarın Girişimcilik boyutunu daha fazla etkilediği söylenebilecektir. Buna ilişkin olarak Modelin anlamlı olduğu söylenebilecektir. Buna göre, Panora AVM sosyal medya kanallarında eğlenceli ve ilgi çekici içerikler paylaştı̆̆ında, tüketicilerinin fikir alışverişinde bulunmalarını sağladığında veya tüketiciye yeni ve güncel bilgiler sunduğunda; tüketiciler tarafindan daha modern, yenilikçi, dışa dönük veya cesur algılanabilecektir. Böylece tüketici tarafından algılanan kurumsal itibarları da yükselebilecektir. 
Tablo 6. Algılanan Sosyal Medya Boyutlarının Kurumsal İtibarda Yetkinlik Boyutu Üzerindeki Etkisine İlişkin Çoklu Regresyon Analizi

\begin{tabular}{lccccccc}
\hline AS2 & $\mathbf{R}^{2}$ adj & $\mathbf{R}^{2}$ & $\mathbf{F}$ & Beta & $\mathbf{P}$ & Tolerans & VIF \\
\hline Model & 0,366 & 0,379 & 29,739 & & & & \\
Ĕglence & & & & 0,197 & $0,009^{*}$ & 0,450 & 2,221 \\
Etkileşim & & & & 0,112 & 0,131 & 0,462 & 2,162 \\
Eğilim & & & 0,240 & $0,000^{*}$ & 0,555 & 1,801 \\
Özelleştirme & & & 0,111 & $0,071^{* *}$ & 0,548 & 1,826 \\
Kulaktan Kulağa İletiş̧im & & & & 0,104 & 0,128 & 0,679 & 1,472 \\
& & & & & & &
\end{tabular}

Bağımlı Değişken: Kurumsal İtibarda Yetkinlik Boyutu; ${ }^{*} \mathrm{p} \leq .05, * * \mathrm{p} \leq .10$

Yapılan bir diğer çoklu regresyon analizinin bağımlı değişkeni kurumsal itibar ölçeğinde yer alan yetkinlik boyutu, bağımsız değişkenler ise algılanan sosyal medya boyutlarıdır (Tablo-6). Analiz sonuçlarına göre, tüketicinin Panora AVM'nin sosyal medyasına yönelik olarak algıladığı Eğlence $(\beta=0,197 ; p<0,05)$, Eğilim $(\beta=0,240 ; p<0,05)$, Özelleştirmenin $(\beta=0,111 ; p<0,10)$ kurumsal itibarın Yetkinlik boyutu üzerine istatistiksel olarak anlamlı ve olumlu yönde etkisi bulunmuştur. Bunun yanı sıra, VIF değerleri incelendiğinde bağımsız değişkenler arasında çoklu doğrusallık problemi olmadığ görülmüştür. Model anlamlıdır ve Beta katsayılarına bakıldığında "Eğilim" boyutunun diğer boyutlara oranla Kurumsal İtibarın Yetkinlik boyutunu daha fazla etkilediği söylenebilecektir. Algılanan Etkileşim ve Kulaktan Kulağa İletişimin ise, Yetkinlik boyutu üzerine anlamlı bir etkisi saptanamamıştır. Buna göre, Panora AVM sosyal medya kanallarında eğlenceli ve ilgi çekici içerikler paylaştığında, tüketiciye yeni ve güncel bilgiler sunduğunda veya tüketiciye ihtiyaca göre düzenlenmiş, bilgi arama olanağı sağladığında daha güvenilir, çalışkan, başarı odaklı, öncü veya kurumsal algılanabilecektir. Böylece tüketici tarafından algılanan kurumsal itibarları da yükselebilecektir. 
Tablo 7. Algılanan Sosyal Medya Boyutlarının Kurumsal İtibarda Şıklık Boyutu Üzerindeki Etkisine İlişkin Çoklu Regresyon Analizi

\begin{tabular}{lcccccccc}
\hline AS2 & $\mathbf{R}^{2}$ adj & $\mathbf{R}^{2}$ & $\mathbf{F}$ & Beta & $\mathbf{P}$ & Tolerans & VIF \\
\hline Model & 0,392 & 0,404 & 33,065 & & & & \\
Ĕglence & & & & 0,180 & $0,015^{*}$ & 0,450 & 2,221 \\
Etkileşim & & & & 0,146 & $0,046^{*}$ & 0,462 & 2,162 \\
Eğilim & & & 0,269 & $0,000^{*}$ & 0,555 & 1,801 \\
Özelleştirme & & & 0,073 & 0,223 & 0,548 & 1,826 \\
Kulaktan Kulağa İletiş̧im & & & & 0,113 & $0,091^{* *}$ & 0,679 & 1,472 \\
& & & & & & &
\end{tabular}

Bağımlı Değişken: Kurumsal İtibarda Şıklık Boyutu; *p $\leq .05, * * p \leq .10$

Yapılan bir diğer çoklu regresyon analizinin bağımlı değişkeni kurumsal itibar ölçeğinde yer alan şıklık boyutu, bağımsız değişkenler ise algılanan sosyal medya boyutlarıdır (Tablo-7). Analiz sonuçlarına göre, tüketicinin Panora AVM'nin sosyal medyasına yönelik olarak algıladığı Eğlence $(\beta=0,180 ; p<0,05)$, Etkileşim $(\beta=0,146 ; \quad p<0,05)$, Eğilim $(\beta=0,269 ; p<0,05)$, Kulaktan Kulağa İletişimin $(\beta=0,113 ; p<0,10)$ kurumsal itibarın Şıklık boyutu üzerine istatistiksel olarak anlamlı ve olumlu yönde etkisi bulunmuştur. Algılanan Özeleştirmenin ise, Şıklık boyutu üzerine anlamlı bir etkisi saptanamamıştır. Bunun yanı sıra, VIF değerleri incelendiğinde bağımsız değişkenler arasında çoklu doğrusallık problemi olmadığ görülmüştür. Buna göre, model anlamlıdır ve Beta katsayılarına göre "Eğilim" boyutunun diğer boyutlara oranla Kurumsal İtibarın Şıklık boyutunu daha fazla etkilediği söylenebilecektir. Buna göre, Panora AVM sosyal medya kanallarında eğlenceli ve ilgi çekici içerikler paylaştığında, tüketicilerin birbirleri ile etkileşimini kolaylaştırdığında, tüketicilerin fikir alışverişinde bulunmalarını sağladığında, tüketiciye yeni bilgiler sunduğunda veya güncellemelerin kullanıcılar arasında kolaylıkla yayılmasına firsat verdiğinde; tüketiciler tarafından daha çekici, stil sahibi, prestijli veya elit olarak algılanabilecektir. Böylece tüketici tarafindan algılanan kurumsal itibarları da yükselebilecektir. 
Tablo 8. Algılanan Sosyal Medya Boyutlarının Kurumsal İtibarda Acımasızlık Boyutu Üzerindeki Etkisine İlişkin Çoklu Regresyon Analizi

\begin{tabular}{|c|c|c|c|c|c|c|c|}
\hline AS2 & $\mathbf{R}^{2}$ adj & $\mathbf{R}^{2}$ & $\mathbf{F}$ & Beta & $\mathbf{P}$ & Tolerans & VIF \\
\hline Model & 0,049 & 0,068 & 3,542 & & & & \\
\hline Eğlence & & & & 0,189 & $0,041^{*}$ & 0,450 & 2,221 \\
\hline Etkileşim & & & & 0,201 & $0,028^{*}$ & 0,462 & 2,162 \\
\hline Ĕgilim & & & & $-0,109$ & 0,192 & 0,555 & 1,801 \\
\hline Özelleştirme & & & & 0,043 & 0,569 & 0,548 & 1,826 \\
\hline $\begin{array}{l}\text { Kulaktan Kulağa } \\
\text { İletişim }\end{array}$ & & & & $-0,154$ & $0,067 * *$ & 0,679 & 1,472 \\
\hline
\end{tabular}

Bağımlı Değiş̧ken: Kurumsal İtibarda Acımasızlık Boyutu; *p $\leq .05,{ }^{* *} \mathrm{p} \leq .10$

Yapılan bir diğer çoklu regresyon analizinin bağımlı değişkeni kurumsal itibar ölçeğinde yer alan acımasızlık boyutu, bağımsız değişkenler ise algılanan sosyal medya boyutlarıdır (Tablo-8). Analiz sonuçlarına göre, tüketicinin Panora AVM'nin sosyal medyasına yönelik olarak algıladığı Eğlence $(\beta=0,189 ; p<0,05)$, Etkileşim $(\beta=0,201 ; p<0,05)$, Kulaktan Kulağa İletişimin $(\beta=-0,154 ; p<0,10)$ kurumsal itibarın Acımasızlık boyutu üzerine istatistiksel olarak anlamlı etkisi bulunmuş ancak bu etki öngörüldüğü gibi olumsuz yönde değildir. Bunun yanı sıra, VIF değerleri incelendiğinde bağımsız değişkenler arasında çoklu doğrusallık problemi olmadığı görülmüş̧ür. Buna göre Model anlamlı değildir, ancak Beta katsayılarına bakıldığında "Etkileşim" boyutunun diğer boyutlara oranla Kurumsal İtibarın Acımasızlık boyutunu daha fazla etkilediği söylenebilecektir. Algılanan Eğilim ve Özelleştirmenin ise, Acımasızlık boyutu üzerine anlamlı bir etkisi saptanamamıştır. Buna göre, Panora AVM sosyal medya kanallarında eğlenceli ve ilgi çekici içerikler paylaştığında, tüketicilerin birbirleri ile etkileşimini kolaylaştırdığında veya tüketicilerin fikir alışverişinde bulunmalarını sağladığında; tüketiciler tarafından bencil, kibirli, otoriter veya kontrolcü olarak algilanmasını engelleyebilecektir. 
Tablo 9. Algılanan Sosyal Medya Boyutlarının Kurumsal İtibarda Kuvvetlilik Boyutu Üzerindeki Etkisine İlişkin Çoklu Regresyon Analizi

\begin{tabular}{lccccccc}
\hline AS2 & $\mathbf{R}^{2}$ adj & $\mathbf{R}^{2}$ & $\mathbf{F}$ & Beta & $\mathbf{P}$ & Tolerans & VIF \\
\hline Model & 0,188 & 0,204 & 12,504 & & & & \\
Ĕglence & & & & 0,001 & 0,988 & 0,450 & 2,221 \\
Etkileşim & & & & 0,153 & $0,070^{* *}$ & 0,462 & 2,162 \\
Eğilim & & & 0,175 & $0,023^{*}$ & 0,555 & 1,801 \\
Özelleştirme & & & 0,048 & 0,489 & 0,548 & 1,826 \\
Kulaktan Kulağa İletiş̧im & & & & 0,175 & $0,024^{*}$ & 0,679 & 1,472 \\
& & & & & & &
\end{tabular}

Bağımlı Değişken: Kurumsal İtibarda Kuvvetlilik Boyutu; *p $\leq .05,{ }^{* *} \mathrm{p} \leq .10$

Yapılan bir diğer çoklu regresyon analizinin bağımlı değişkeni kurumsal itibar ölçeğinde yer alan kuvvetlilik boyutu, bağımsız değişkenler ise algılanan sosyal medya boyutlarıdır (Tablo-9). Analiz sonuçlarına göre, tüketicinin Panora AVM'nin sosyal medyasına yönelik olarak algıladığı Etkileşim $(\beta=0,153$; $p<0,10)$, Eğilim $(\beta=0,175 ; p<0,05)$, Kulaktan Kulağa İletişimin $(\beta=0,175 ; p<0,05)$ kurumsal itibarın Kuvvetlilik boyutu üzerine istatistiksel olarak anlamlı $(p<0,01)$ ve olumlu yönde etkisi bulunmuştur. Algılanan Eğlence ve Özeleştirmenin ise, Kuvvetlilik boyutu üzerine anlamlı bir etkisi saptanamamıştır. Bunun yanı sıra, VIF değerleri incelendiğinde bağımsız değişkenler arasında çoklu doğrusallık problemi olmadığ 1 görülmüştür. Buna göre, model anlamlıdır ve Beta katsayılarına göre "Eğilim" ve "Kulaktan Kulağa İletişim" boyutları "Etkileşim" boyutuna göre Kurumsal İtibarın Kuvvetlilik boyutunu daha fazla etkiledikleri söylenebilecektir. Başka bir ifade ile Panora AVM sosyal medya kanallarında tüketicilerin birbirleri ile etkileşimini kolaylaştırdığında, tüketicilerin fikir alışverişinde bulunmalarını sağladığında, tüketiciye yeni bilgiler sunduğunda veya güncellemelerin kullanıcılar arasında kolaylıkla yayılmasına firsat verdiğinde; tüketiciler tarafından daha sert veya dayanıklı olarak algılanabilecektir. Böylece AVM'nin tüketici tarafından algılanan kurumsal itibarları da yükselebilecektir. 
Tablo 10. Algilanan Sosyal Medya Boyutlarının Kurumsal İtibarda Ulaşılabilirlik Boyutu Üzerindeki Etkisine İlişkin Çoklu Regresyon Analizi

\begin{tabular}{llllllll}
\hline AS2 & $\mathbf{R}^{2}$ adj & $\mathbf{R}^{2}$ & $\mathbf{F}$ & Beta & $\mathbf{P}$ & Tolerans & VIF \\
\hline Model & 0,088 & 0,107 & 5,817 & & & & \\
Ĕglence & & & & 0,198 & $0,029^{*}$ & 0,450 & 2,221 \\
Etkileşim & & & & 0,049 & 0,580 & 0,462 & 2,162 \\
Eğilim & & & & $-0,013$ & 0,873 & 0,555 & 1,801 \\
Özelleştirme & & & & 0,008 & 0,916 & 0,548 & 1,826 \\
Kulaktan Kulağa İletişim & & & & 0,131 & 0,110 & 0,679 & 1,472 \\
\end{tabular}

Bağımlı Değişken: Kurumsal İtibarda Ulaşılabilirlik Boyutu; *p $\leq .05$

Yapılan bir diğer çoklu regresyon analizinin bağımlı değişkeni kurumsal itibar ölçeğinde yer alan ulaşılabilirlik boyutu, bağımsız değiş̧kenler ise algılanan sosyal medya boyutlarıdır (Tablo-10). Analiz sonuçlarına göre, tüketicinin Panora AVM'nin sosyal medyasına yönelik olarak algıladığı Eğlencenin $(\beta=0,198$; $\mathrm{p}<0,05)$ kurumsal itibarın Ulaşılabilirlik boyutu üzerine istatistiksel olarak anlamlı ve olumlu yönde etkisi bulunmuştur. Algilanan Etkileşim, Eğilim, Özelleştirme ve Kulaktan Kulağa İletişimin ise, Ulaşılabilirlik boyutu üzerine anlamlı bir etkisi saptanamamıştır. Bunun yanı sıra, VIF değerleri incelendiğinde bağımsız değişkenler arasında çoklu doğrusallık problemi olmadığı görülmüştür. Model anlamlıdır. Buna göre, AVM'ler sosyal medya kanallarında eğlenceli ve ilgi çekici içerikler yayınladığında veya tüketicilerle bilgi paylaşımda bulunduğunda; tüketiciler tarafindan daha mütevazı ve kolay ulaşılabilir olarak algılanabilecektir. Böylece tüketici tarafından algılanan kurumsal itibarları da yükselebilecektir.

\section{Sonuç}

\section{1.Çalışmanın Teorik Katkıları}

Dijital ortamda itibar yönetimi ve bu itibarın korunması süreçlerinde başarılı olabilmek adına işletmelerin bu ortamda sosyal medya ortamında aktif olarak yer alması gerekmektedir. Bilbil ve Güler'e (2017) göre işletmeler, kurumsal itibarlarını etkileyen birçok faktörü dijital ortama taşıyarak kendisini paydaşlarına tanıtabilecek, etkileşim kurabilecek, sosyal müşteri ilişkileri yönetimiyle müşterilerin ihtiyaçlarına hızlı yanıt verebilecek ve dijital ortamda kriz yönetimi yapabilecektir. Dolayısıyla çalışmanın temel amacı; tüketicinin, markaların sosyal medya pazarlama faaliyetlerine yönelik algıları ile algıladı̆̆ı kurumsal itibar arasındaki ilişkinin incelenmesidir. $\mathrm{Bu}$ anlamda çalışma, kurumsal itibarın "kişiselleştirme metaforu" kullanılarak ölçülmesi ve kurumsal itibar ile sosyal medya algısı boyutlarının ayrı ayrı etkilerinin incelenmesi bakmından literatüre katkı sağlayabilecektir. Ek olarak, çalışmanın bir AVM'nin sosyla medya uygulamalrı kullanılarak yapılması ve AVM itibarının ölçülmesi nedeni ile, AVM 
sektörüne katkıda bulunması beklenmektedir. Bu amaç doğrultusunda yapılan analizlerin sonuçlarına göre, tüketicilerin AVM'ye ilişkin sosyal medya algıları, AVM'nin kurumsal itibarına yönelik algılarını olumlu yönde etkilemektedir. Literatürde yer alan bir çalışmada da (Dijkmans vd., 2015), havaalanı sektörü için benzer bir sonuca ulaşılmış, tüketicilerin kurumsal sosyal medya ile etkileşiminin (bilgi düzeyinin ve takip etme sıklığının) artması sonucunda, havaalanı kurumlarının itibarını da daha yüksek algıladıkları ortaya konmuştur. Bu anlamda çalışmanın temel bulgusu literatürü destekler niteliktedir.

Çalışmanın daha detaylı bulguları, her bir sosyal medya algısı boyutunun kurumsal itibar algısı boyutları üzerine etkilerini ayrı ayrı ortaya koymuş ve dijital ortamda kurum itibarı yönetimi için teorik katkı oluşturmuştur. Bu nedenle, kurumsal itibar algısını ve sosyal medya algısını çok boyutlu olarak ele almak çalışmanın önemli katkılarından bir diğeridir. Söz konusu detaylı bulgular eşliğinde dijital araçlar ile itibar yönetimi hakkında şunlar söylenebilecektir;

Kurumların sosyal medya sayfasının yeni gelişmeleri takip ediyor olması, tüketiciler arasında etkileşim ve iletişim (örn. elektronik kulaktan kulağa iletişim) sağlamas1; ilgili kurumun güvenilir, kuvvetli (maskülen) ve yeni trendleri (moday1) takip ediyor şeklinde algılanmasına neden olabilecektir. Bir kurumun sosyal medya sayfası tüketiciler tarafindan eğlenceli olarak algılanması da önem taşımaktadır, bu şekilde tüketici kurumu yine yeni trendleri (modayı) takip ediyor şeklinde algılayabilecektir. Tüketicinin sosyal medya sayfasını yeterli etkileşime olanak sağlıyor şeklinde algılaması ise, kurumun girişimci ve şık olarak algılanmasına sebebiyet verebilecektir. Eğer bir kurumun sosyal medya sayfası aynı zamanda eğlenceli, etkileşim sağlayan ve ek olarak kişiselleştirmeye olanak sağlar şekilde algılanıyorsa, o kurumun yetkin (uzman) olarak algılanmasına neden olabilecektir. Yalnızca eğlenceli olan bir kurumsal sosyal medya sayfası ise ulaşılabilir (resmi olmayan) bir kurum algısı yaratabilecektir. Bunlardan farklı olarak tüketiciler, eğlencenin, etkileşimin ve iletişimin olmadığ sayfalarına sahip olan kurumları acıması (bencil ve otoriter) algilayabilmektedirler.

\section{2.Çalışmanın Pratik Katkıları}

Kurumsal itibar ve sosyal medya algısını çok boyutlu olarak ele almak çalışmanın pratik katkılarını da zenginleştirmektedir. Çalışmada Panora AVM'nin sosyal medya algısının, Panora AVM'nin kurumsal itibar algısı üzerine etkileri incelenmiştir. $\mathrm{Bu}$ doğrultuda çalışma, AVM sektörü özelinde pratik katkılara sahiptir.

Buna göre; tüketicilerin kendi fikir ve önerilerini bir işletmenin sosyal medya sayfalarında diğerleri ile paylaşabilmesi, sayfanın içeriklerinin yeni ve güncel olması, bu içeriklerin tüketicilerin de paylaşmak isteyeceği türden olması, sayfanın tüketiciye bilgi akışı sağlanması, tüketicilerin işletmeyi daha cana yakın, 
samimi, arkadaş, canlısı veya duyarlı algılamalarını sağlayabilecektir. Böylece işletmenin kurumsal itibarı da daha yüksek algılanabilecektir. Dolayısıyla AVM'ler sosyal medya paylaşımlarının güncel ve paylaşım içeriklerinin tüketiciler tarafından ilgi çekecek şekilde olmasına özen göstermelidir. Böylelikle hantal yapılara sahip olan AVM'ler tüketicinin gözünde daha cana yakın, samimi, arkadaş, canlısı veya duyarlı olabilecektir.

Ayrıca bir işletmenin sosyal medya sayfasının tüketiciler tarafından eğlenceli olarak algılanması; içeriklerin ilgi çekici bulunması, tüketiciyle bağ kurabilmesi, tüketicilerin diğerleri ile fikir alışverişi sağlamasını kolaylaştırması ve güncel olması, işletmenin sosyal medya sayfasının karizmatik, genç, modayı takip eden, yenilikçi, dışa dönük ve cesur olarak algılanmasına katkı sağlamaktadır. $\mathrm{Bu}$ nedenle, AVM'lerin sosyal medya hesaplarının eğlenceli olarak algılanabilmesi adına gerçekleştirecekleri interaktif, gündemi yakalayan veya mizah ögeleri içeren paylaşımlar; markanın yenilikçi, genç, dışa dönük ve cesur olarak algılanmasına katkı sağlayabilecektir.

Yayınlanan içeriklerin ilgi çekici ve güncel olmasının, kullanıcının ihtiyacına göre düzenlenmiş bilgi arama olanağı sağlaması; AVM'nin sosyal medya sayfalarının aynı zamanda güvenilir, kendinden emin, çalışkan, istekli, başarı odaklı, öncü ve kurumsal olarak algılanmasına katkı sağlamaktadır. AVM'lerin içerisinde çok sayıda markayı barındırması, yoğun bir müşteri trafiği olması gibi nedenlerle, sosyal medyadan gelen herhangi bir soruya yönelik uygun yanıtları, ihtiyaca göre düzenlenmiş ve hılı bir şekilde tüketiciye sunabiliyor olması; işletmenin güvenilir, kendinden emin ve daha kurumsal algılanmasını destekleyebilecektir.

Şıklık, markanın stil sahibi, prestijli ve elit olması gibi ögelerle şekillenmektedir. Bu ögeler Davies vd. $(2004,141)$ tarafından, özellikle moda sektöründe hizmet veren markalar için oldukça önemli bulunmuştur. Dolayısıyla moda sektöründen çok sayıda markayı barındıran ve üst segmentteki tüketici kitlesine hitap eden Panora AVM'nin sosyal medya iletişimi ile tüketicide yarattığı algının, markanın tüketici tarafından prestij sahibi olarak algılanmasına katkı sağlaması öngörülmüştür. Nitekim, yapılan analizler sonucunda Panora AVM'nin sosyal medya sayfalarının eğlenceli olarak algılanmasının, yayınlanan içeriklerin ilgi çekici olmasının, bu sayfaların tüketiciyle bilgi paylaşımı yoluyla bağ kurabilmesinin, kullanıcıya diğer tüketicilerle konuşmak ve fikir alışverişi sağlamak için firsat vermesinin, yayınlanan içeriklerin yeni olmasının ve son olarak tüketicilerin kişisel sosyal medya sayfalarında paylaşmak isteyebileceği içeriklerin bulunmasının; Panora AVM'nin sosyal medya sayfalarının aynı zamanda prestijli, çekici, stil sahibi, zarif, ince ruhlu ve elit olarak algılanmasına katkı sağladığı görülmektedir. AVM'lerin sosyal medyada paylaşılmak üzere ilgi çekici, güncel, paylaşılabilir içerikler hazırlarken, estetik bir kaygıya sahip olmaları ve içeriklerin görsel olarak da ilgi çekici olmasını gözetmeleri, stil sahibi ve prestijli algılanmalarına katkı sağlayabilecektir. 
Kurumsal itibar algısında acımasızlık boyutu genel olarak bencil, kontrolcü, otoriter ve kibirli gibi kişilik sıfatları ile şekillenen, olumsuz anlam ifade eden bir boyuttur. Dolayısıyla, algılanan sosyal medya boyutlarının tamamının, acımasızlık boyutu üzerinde olumsuz etkisi olması öngörülmüştür. Fakat analizler sonucunda Panora AVM'nin sosyal medya sayfalarının eğlenceli algılanmasının, yayınlanan içeriklerin ilgi çekici olmasının, bu sayfaların tüketiciyle bilgi paylaşımı yoluyla bağ kurabilmesinin, kullanıcıya diğer tüketicilerle konuşmak ve fikir alışverişi sağlamak için firsat vermesinin Panora AVM'nin sosyal medya sayfalarının aynı zamanda kibirli, bencil, otoriter ve kontrolcü olarak algılanmasına katkı sağladığı görülmektedir. Markanın yürüttüğü sosyal medya iletişiminin bu boyutları, kurumsal kişilik içerisinde yer alan diğer olumlu boyutları olumlu etkilerken, aynı zamanda olumsuz bir boyut olan acımasızlık boyutunu da olumlu etkilediği için; tüketicinin acımasızlık boyutunda yer alan ifadeleri markayla ilgili olumsuz özellikler olarak algılamadığı düşünülmüştür. Dolayısıyla günümüz üst segment AVM tüketicisinin bir markadan prestij, yetkinlik, modernlik, samimiyet gibi özellikler beklemesinin yanı sıra kibirli ve bencil bir duruşu olmasını beklediği çıkarımı yapılabilmektedir.

Çalışmanın birçok bölümünde aktarıldığı gibi, kurumsal itibar algısının kişilik sıfatları, yani kişiselleştirme metaforu ile ölçülmek istenilmesinin altında yatan temel sebeplerden biri artık kurumlarda ve markalarda insan doğasının ve insana ait özelliklerin kendini açıkça göstermesidir. İnsanın doğasında var olan kibirli olma, bencillik, otoriterlik gibi kişilik özelliklerinin; söz konusu tüketici tarafından, markayı kendisiyle daha kolay özdeşleştirebildiği için olumsuz özellikler olarak algılanmadığı sunucuna ulaşılabilmektedir.

Panora AVM'nin sosyal medya sayfalarının, kullanıcıya diğer tüketicilerle konuşmak ve fikir alışverişi sağlamak için fırsat vermesinin, yayınlanan içeriklerin yeni olmasının ve tüketicilerin kişisel sosyal medya sayfalarında paylaşmak isteyebileceği içeriklerin bulunmasının; Panora AVM'nin mücadeleci, dayanıklı ve sert olarak algılanmasına katkı sağladığı görülmektedir. Ek olarak, Panora AVM'nin sosyal medya sayfalarının eğlenceli algılanmasının, yayınlanan içeriklerin ilgi çekici olmasının, bu sayfaların tüketiciyle bilgi paylaşımı yoluyla bağ kurabilmesinin, Panora AVM'nin aynı zamanda gayri resmi, mütevazı ve kolay ulaşılır olarak algılanmasına katkı sağladığı görülmektedir.

Sonuç olarak, çalışmada AVM'lerin tüketici tarafindan algılanan kurumsal itibarlarını arttırabilmek adına sosyal medyayı nasıl kullanmaları ve neler paylaşmaları gerektiği ile ilgili önemli çıkarımlar yapılmıştır. Çalışmanın örnekleminin çoğunlukla söz konusu AVM'yi Instagram'da takip ettiğini belirtmesi dolayısıyla çalışmada elde edilen sonuçlar Instagram paylaşımları için daha geçerli olabilecektir. Bu çalışmada diğer birçok çalışmadan farklı olarak, kurumsal itibar algısı "kişiselleştirme metaforu" ile ölçülmüş ve sosyal medya 
kullanımının bu ölçek içerisinde yer alan her bir boyut üzerindeki etkisi araştırılmıştır.

\section{3.Çalışmanın Kısıtları ve Gelecek Çalışmalar için Öneriler}

Her çalışma gibi bu çalışmanın da sınırlandırmaları mevcuttur. Panora AVM'nin sosyal medya kullanıcılarına ait bir listeye ulaşılamadığı için, örneklem seçimi tesadüfi yöntemlerle yapılamamıştır. Dolayısıyla veriler, kolayda örneklem yöntemi ile toplanmıştır. Analizler sonucunda verilerin tesadüfilik gösterdiği tespit edilse de sonraki çalışmalarda tesadüfi yöntemlerle seçilen bir örneklemin, çalışmanın genellenebilirliğini arttıracağı öngörülmektedir. Toplanan verilerin büyük bir kısmını üniversite mezunlarından oluşmaktadır. $\mathrm{Bu}$ kitlenin ise markaları genellikle Instagram üzerinden takip ettiği görülmektedir. Dolayısıyla hem eğitim düzeyi hem de kullanılan sosyal medya kanalı için elde edilen verilerle, bu kategorilerde bir genelleme yapılamayacak olması bu araştırmanın sınırlandırmalarından biri olmuştur. $\mathrm{Bu}$ doğrultuda, çalışmada demografik özelliklerin belirlediği gruplar arasındaki farklılıkların analiz edilmemesi bu çalışma için bir sınırlandırma olarak belirlenmiştir.

Farklı grupların da araştırmaya dâhil olması ve modeldeki ilişkilerin, demografik faktörlerin düzenleyici etkilerinin de ele alınmasıyla değerlendirilmesi gelecekteki çalışmaların literatüre katkısı olabilir. Farklı sektörlerde çok boyutlu yapılar ölçülebilir ve boyutların etkileri karşılaştırılabilir. 


\section{Kaynakça}

Aaker, J. L. (1997). Dimensions of brand personality. Journal of Marketing Research, 347-356.

Andreassen, T. W. ve Lindestad, B. (1998). The effect of corporate image in the formation of customer loyalty. Journal of Service Research, 1(1), 82-92.

Aula, P. (2010). Social media, reputation risk and ambient publicity management. Strategy \& Leadership, 38(6), 43-49.

Aydın, A. F. (2015). Kurumsal itibar açısından sosyal medyaya ilişkin bir değerlendirme. Karadeniz Teknik Üniversitesi İletişim Araştırmaları Dergisi, 1(9), 1-15.

Benlian, A. ve Hess, T. (2011). Opportunities and risks of software-as-a-service: Findings from a survey of IT executives. Decision support systems, 52(1), 232-246.

Bennett, R. ve Gabriel, H. (2001). Reputation, trust and supplier commitment: the case of shipping company/seaport relations. Journal of Business \& Industrial Marketing, 16(6), 424-438.

Berens, G. (2004). Corporate branding: the development of corporate associations and their influence on stakeholder reactions. Erasmus University Rotterdam

Bilbil, E. K. ve Güler, Ş. (2017). Dijital Ortamda Kurumsal İtibar Yönetimi ve Viral Uygulamalar İlişkisi. Global Media Journal: Turkish Edition, 7(14).

Boateng, S. L. (2019). Online relationship marketing and customer loyalty: a signaling theory perspective. International Journal of Bank Marketing. $37(1)$.

Chi, H. H. (2011). Interactive digital advertising vs. virtual brand community: Exploratory study of user motivation and social media marketing responses in Taiwan. Journal of Interactive Advertising, 12(1), 44-61.

Çiftçi, D. B. İ. M., İşler, D. B., Çiftçi, M. ve Yarangümelioğlu, D. (2015). Halkla ilişkiler aracı olarak: Sosyal medyanın kullanımı ve yeni stratejiler. Sosyal ve Beşeri Bilimler Dergisi, 5(1), 174-185.

Culnan, M. J., McHugh, P. J. ve Zubillaga, J. I. (2010). How large US companies can use Twitter and other social media to gain business value. MIS Quarterly Executive, 9(4). 
Davies, G., Chun, R., da Silva, R. V. ve Roper, S. (2001). The personification metaphor as a measurement approach for corporate reputation. Corporate Reputation Review, 4(2), 113-127.

Davies, G. ve Chun, R. (2003). The use of metaphor in the exploration of the brand concept. Journal of Marketing Management, 19(1-2), 45-71.

Davies, G., Chun, R., da Silva, R. V. ve Roper, S. (2004). A corporate character scale to assess employee and customer views of organization reputation. Corporate Reputation Review, 7(2), 125-146.

Demir, F. O. (2010). Kurumsal itibar ölçümünde kişiselleştirme metaforu. Review Of Social, Economic and Business Studies, 9, 10248-10249.

Dijkmans, C., Kerkhof, P. ve Beukeboom, C. J. (2015). A stage to engage: Social media use and corporate reputation. Tourism Management, 47, 58-67.

Erdoğmuş, İ. E., ve Cicek, M. (2012). The impact of social media marketing on brand loyalty, 8th International Strategic Management Conference Bildiri Kitabi. Elsevier

Evans, D. (2010). Social media marketing: An hour a day. John Wiley \& Sons.

Evans, W. D. (2008). Social marketing campaigns and children's media use. The Future of Children, 18(1), 181-203.

Firat, A. F. ve Venkatesh, A. (1996). Postmodern perspectives on consumption. Consumption and marketing: Macro Dimensions, 234-265.

Floreddu, P. B., Cabiddu, F. ve Evaristo, R. (2014). Inside your social media ring: How to optimize online corporate reputation. Business Horizons, 57(6), 737-745.

Gensler, S., Völckner, F., Liu-Thompkins, Y. ve Wiertz, C. (2013). Managing Brands in the Social Media Environment. Journal of Interactive Marketing, 27(4), 242-256.

George, D. ve Mallery, P. (2003). SPSS for Windows step by step: A simple guide and reference. 11.0 update (4th ed.). Boston: Allyn \& Bacon

Gordhamer, S. (2009). 4 ways social media is changing business. Mashable-The Social Media Guide. Erişim adresi: https://mashable.com/2009/09/22/social-media-business/\#gDSmO4spaiqN

Gotsi, M. ve Wilson, A. M. (2001). Corporate reputation: seeking a definition. Corporate communications: An International Journal, 6(1), 24-30. 
Groom, S.A. (2008). Integrated marketing communication: Anticipating the 'age of engage.' Communication Research Trends, 27, 3-19.

Hair, J.F., Black, W.C., Babin, B.J. ve Anderson, R.E. (2010). Multivariate Data Analysis. ABD: Pearson.

Heinonen, K. (2011). Consumer activity in social media: Managerial approaches to consumers' social media behavior. Journal of Consumer Behaviour, 10(6), 356-364.

Hudson, S., Roth, M. S., Madden, T. J. ve Hudson, R. (2015). The effects of social media on emotions, brand relationship quality, and word of mouth: An empirical study of music festival attendees. Tourism Management, 47, 68-76.

Hoffman, D. L. ve Fodor, M. (2010). Can you measure the ROI of your social media marketing? MIT Sloan Management Review, 52(1), 41.

Inoue, T., Matsuoka, H. ve Arai, H. (2016). The Relationship between Perceived Social Media Marketing Activities of J. League Clubs and Behavioral Intention of Spectators. Asian Sports Management Review, (11), 3-20.

Ismail, A. R. (2017). The influence of perceived social media marketing activities on brand loyalty: The mediation effect of brand and value consciousness. Asia Pacific Journal of Marketing and Logistics, 29(1), 129-144.

Kaplan, A. M. ve Haenlein, M. (2010). Users of the world, unite! The challenges and opportunities of Social Media. Business horizons, 53(1), 59-68.

Kaur, G. (2016). Social Media Marketing. Asian Journal of Multidisciplinary Studies, 4(7).

Kavak, B. (2013). Pazarlama ve pazar araştırmaları/tasarım ve analiz. Ankara: Detay Yayıncilik.

Kim, A. J. ve Ko, E. (2012). Do social media marketing activities enhance customer equity? An empirical study of luxury fashion brand. Journal of Business Research, 65(10), 1480-1486.

Larson, K. ve Watson, R. (2011). The value of social media: toward measuring social media strategies. Thirty Second International Conference on Information Systems, Shanghai 2011

Laroche, M., Habibi, M. R. ve Richard, M. O. (2013). To be or not to be in social media: How brand loyalty is affected by social media?. International journal of information management, 33(1), 76-82. 
Lempert, P. (2006). Caught in the Web. Progressive Grocer, 85(12), 15-28.

MacMillan, K., Money, K., Downing, S. ve Hillenbrand, C. (2005). Reputation in relationships: measuring experiences, emotions and behaviors. Corporate Reputation Review, 8(3), 214-232.

Morgan, G. (1983). More on metaphor: Why we cannot control tropes in administrative science. Administrative Science Quarterly, 28 (4), 601-607.

Nguyen, N. ve Leblanc, G. (2001). Corporate image and corporate reputation in customers' retention decisions in services. Journal of retailing and Consumer Services, 8(4), 227-236.

Ostrowski, P.L., O'Brien, T.V., Gordon, G.L. (1993). Service quality and customer loyalty in the commercial airline industry. Journal of Travel Research, 32 (2), 16-24.

Odabaş1, Yavuz (2004), Postmodern Pazarlama - Tüketim ve Tüketici, İstanbul: MediaCat Yayınları.

Packer, R. (2011). Social media marketing. The Art of Conversational Sales. WSI.

Robertson, T.S. (1993). How to reduce market penetration cycle times. Sloan Management Review, 35 (1), 87-96.

Seo, E. J. ve Park, J. W. (2018). A study on the effects of social media marketing activities on brand equity and customer response in the airline industry. Journal of Air Transport Management, 66, 36-41.

Shapiro, C. (1982). Consumer information, product quality, and seller reputation. The Bell Journal of Economics, 13, 20-35.

Tiago, M. T. P. M. B. ve Veríssimo, J. M. C. (2014). Digital marketing and social media: Why bother?. Business Horizons, 57(6), 703-708.

Tripp, T. M. ve Grégoire, Y. (2011). When unhappy customers strike back on the Internet. MIT Sloan Management Review, 52(3), 37-44.

Tabachnick, B. G. ve Fidell, L. S. (2013). Using multivariate statistics. Amerika Birleşik Devletleri, Pearson.

Tuten, T. L. ve Solomon, M. R. (2017). Social media marketing. Sage.

Weinberg, T. (2009). The new community rules: Marketing on the social web. O’Reilly Media, Inc. 
Weinberg, B. D. ve Pehlivan, E. (2011). Social spending: Managing the social media mix. Business Horizons, 54(3), 275-282.

Yadav, M. ve Rahman, Z. (2017). Measuring consumer perception of social media marketing activities in e-commerce industry: Scale development \& validation. Telematics and Informatics, 34(7), 1294-1307.

Yoon, E., Guffey, H.G. ve Kijewski, V. (1993). The effects of information and company reputation on intentions to buy a business service. Journal of Business Research, 27, 215-228.

Zarrella, D. (2009). The social media marketing book. O'Reilly Media, Inc. 


\title{
Effects of Perceived Social Media Marketing on Corporate Reputation Perception: Personification Metaphor
}

\author{
Extended Abstract
}

\section{Introduction}

The main purpose of this study is to examine the relationship between the consumer perception of the social media marketing activities of the brands and the corporate reputation perceived towards the brand. This study can contribute to the literature in terms of measuring corporate reputation using the "personification metaphor" and examining the separate effects of corporate reputation and social media perception dimensions. Another contribution of the study is to adopt an approach in which the perceptions, desires and characteristics of the individual are at the forefront by focusing on the concept of "individual" in measuring perceptions of social media marketing and corporate reputation. In the study, the social media perception of the consumer towards Panora Shopping Mall was measured and the effects of this understanding on the corporate reputation of Panora Shopping Mall were examined, and in line with the findings obtained, strategies specific to the shopping mall sector were proposed.

\section{Conceptual Framework}

In this study, the social media marketing perception is considered as a conceptual structure consisting of five dimensions. Accordingly, the Entertainment dimension includes enjoying and having fun in the social media activities of the brand in question; the Interaction dimension includes the interaction, information sharing and exchange of ideas among those who use the social media account of the brand in question; the Trendiness dimension includes the social media of the brand adapting to new developments; the Customization dimension includes the social media account of the brand providing personalized, customized information and content; and lastly, the Word of Mouth (WoM) dimension includes the tendency of the brand transmitting and spreading the information acquired by social media users to others through social media accounts (Kim \& Ko, 2012).

In this study, the use of personification metaphor has been adopted to measure the perception of corporate reputation. The Personification Metaphor is a method that evaluates a business by equating it with an individual and contributes to the understanding of the complex structure by referring to something familiar (Morgan, 1983).

Accordingly, Davies et al. (2001), using the Big Five Personality Traits, which defines the personality traits of Aaker (1997), presented a seven-dimensional corporate reputation scale (Berens, 2004) and conceptualized the use of Personification Metaphor. Accordingly, the Aggreableness dimension, one of the basic features of corporate personality, corresponds to the concepts of trust in the brand literature and social responsibility in the reputation literature. The Ruthlessness dimension in the scale is the only dimension with a negative meaning. This is a dimension that generally includes personification adjectives such as selfish, controlling, authoritarian and arrogant (Davies et al., 2004). Enterprise dimension means extroversion in personality literature. Businesses with high enterprise scores are perceived as innovative, exciting, young, and modern. The Competence dimension, which is also included in the brand personality scale of Aaker (1997), is a concept that should be taken into consideration while managing the corporate reputation of the enterprises. The Chic dimension is in accord with the cultural dimension of the brand personality (Aaker, 1997). In the corporate literature, it points more to the concept of reputation and relatively higher scores can be obtained in specialized sectors such as 
fashion. The Machismo dimension is defined as the gender dimension of corporate personality in parallel with its use in the brand personality scale. It indicates a relatively harsh communication style between employees and customers. The Informality dimension refers to informality in matters such as the dress code of employees in the organization and communication with the customer (Davies et al., 2004). In the light of the literature review, a research model is proposed to measure the effects of the dimensions of social media perception on the dimensions of corporate reputation, measured by the personification metaphor approach.

\section{Method}

The perceived social media scale in the study was taken from the researches of Kim and Ko (2012). The corporate reputation scale in the study is taken from the research of Davies et al. (2004). The relevant scale items are measured with a 5-point Likert Scale ranging from "Strongly Disagree" to "Strongly Agree". The population of this research consists of social media users who follow the social media accounts of Panora Shopping Mall in Ankara, Turkey. As the sampling method, one of the non-probabilistic methods, the convenience sampling method was used. The sample size was determined to be 250 , data was collected during November of 2018.

\section{Results and Discussion}

The findings of the study separately revealed the effects of each social media perception dimension on the dimensions of corporate reputation perception, and the theoretical contribution to corporate reputation management in the digital environment. For this reason, handling corporate reputation perception and social media perception in a multidimensional way is one of the important contributions of this study. With these detailed findings, the following can be said about reputation management with digital tools:

The social media pages of corporations following new developments, providing interaction and communication among consumers (eg electronic word of mouth) could cause the corporation to be perceived as being reliable, strong (masculine) and following new trends (fashion). It is also important that a corporation's social media page is perceived as entertaining by consumers so that the consumer will be able to perceive the corporation as following new trends (fashion). If the consumer perceives the social media page as allowing sufficient interaction, it may cause the corporation to be perceived as entrepreneurial and stylish. If a corporation's social media page is perceived as entertaining, interactive, and allowing additional personalization, it may cause the corporation to be perceived as competent (expert). A corporate social media page which is only fun can create an accessible (informal) corporate perception. Unlike these, consumers may perceive corporation that have social media pages without entertainment, interaction and communication as ruthless (selfish and authoritarian). 